Teologia i Moralność, volumen 16(2021), numer 2(30)

doi: 10.14746/TIM.2021.30.2.1

ORCID: 0000-0002-3962-1950

JERZY BRUSIŁO

Uniwersytet Papieski Jana Pawła II w Krakowie

Wydział Teologiczny

\title{
Pytania o życie ludzkie i znaczenie Ewangelii życia Jana Pawła II
}

\section{Wstęp}

Czym jest fenomen, osobliwość życia? Skąd pochodzi życie na Ziemi? Jakie znaczenie ma życie w istniejącej materii $\mathrm{w}$ ogóle i jakie ma ono znaczenie dla człowieka?

Oto ważne pytania, z którymi mierzą się nauki przyrodnicze i na które nauka o życiu nie znajduje odpowiedzi, pozostawiając „,zarną dziurę w samym sercu biologii" (Lane 2016, 9). To pytania, które stawia nauka i pytania, na które szuka odpowiedzi człowiek, zastanawiając się nad życiem w ogóle, nad światem istot żywych i nad swoim życiem. I to są pytania najczęściej z dziedziny nauk przyrodniczych (m.in. biologii, fizjologii, biochemii), które domagają się również odpowiedzi humanistycznych, filozofii czy teologii, i to nie tylko od ludzi wierzących, chrześcijan czy wyznawców jakiejkolwiek religii (Wielka encyklopedia PWN 2005, 560-562; Encyklopedia katolicka 2014, 1624-1628).

Czy może pomóc tu teologia i odniesienie do życia ludzkiego, które jest szczytowym, uduchowionym przejawem życia w ogóle? Czy odkrycie sensu życia ludzkiego pozwoli na lepsze zrozumienie istnienia, osobliwości jakiejkolwiek formy życia?

Od ustalenia granic zrozumienia życia biologicznego, przyrodniczego, przez teologiczne odczytanie wyjątkowości nieśmiertelnego życia człowieka, można dojść do odkrycia Ewangelii życia ludzkiego (w szerszym rozumieniu - idei), która - w wydaniu Jana Pawła II - zawiera w sobie „Ewangelię życia", w węższym, ścisłym rozumieniu z jego encykliki Evangelium 
$v_{i t a e^{1}}$. Sam Autor tego dokumentu wskazuje na pochodzenie „Ewangelii życia”, która „znajduje się w samym sercu orędzia Jezusa Chrystusa” i „nie znajduje się wprawdzie w Piśmie świętym jako takie, ale odpowiada ono dobrze istotnej treści orędzia biblijnego" (Jan Paweł II 1995a, 1-2).

Czy propozycja Ewangelii życia z całego nauczania Jana Pawła II jest dobrą odpowiedzią na te pytania?

\section{1. Życie w wymiarach przyrodniczych}

Najkrótsze, zwięzłe określenie zjawiska życia znajduje się w dwudziestotomowej Wielkiej Encyklopedii Oxfordzkiej: „Zjawisko biologiczne, które charakteryzuje się zdolnością do wzrostu, rozmnażania się, ewolucji, homeostazy, reakcją na bodźce takie jak światło, ciepło i dźwięk, metabolizmem, ruchem". Natomiast jego powstanie jest opisane w tym samym miejscu następująco: „Jedynym obecnie znanym sposobem powstawania życia jest tworzenie go przez organizmy żywe" (Wielka Encyklopedia Oxford 2010, 289-290). To nie wszystko, bo gdy zwrócimy uwagę na życie człowieka, odkryje się przed nami życie nie tylko przyrodzone, biologiczne.

Być może nauka znajdzie kiedyś zadowalającą, pełną odpowiedź na postawione wyżej pytania o życie, ale będzie to tylko materialne, biologiczne, fizyczne, biochemiczne czy jakiekolwiek inne informacyjne (Zięba 2020), kosmiczne (Baturo 2011, 167, 169) opisanie życia jako charakterystycznych cech nieobecnych w świecie nieożywionym: zdolności samoorganizacji przez przechowanie i kopiowanie informacji w postaci jednej lub dwóch nici DNA (kwasu dezoksyrybonukleinowego), trzech podstawowych funkcji - przemiany materii, wzroście (ruchu) i rozmnażania się, autoreprodukcji (Schockenhoff 2014, 9; Caroll 2017) - albo w skrajnie materialnej, fizyko-chemicznej odpowiedzi co do celu życia: „To proste. Celem życia jest uwodornienie dwutlenku węgla" (Michael Russell, geochemik Jet Propulsion Laboratory, NASA) (Caroll 2017, 328).

Życie ma szereg wymiarów przyrodzonych. Przede wszystkim pierwszy, podstawowy wymiar to istnienie jako „osobliwość” (określenie cechy materii ożywionej), która różni się ontologicznie od materii nieożywionej tak bardzo jak materia od nicości (braku materii) i która nie mogłaby powstać przypadkowo i sama z siebie (Caroll 2017, 342) ${ }^{2}$. Następny wymiar to swoiste (inne

\footnotetext{
${ }^{1}$ Ze względu na jednobrzmiące określenia ogólnej koncepcji Ewangelii życia i „Ewangelii życia" z encykliki Evangelium vitae tego samego Autora pierwsze ze sformułowań w tekście artykułu będzie podane bez cudzysłowu, natomiast drugie w cudzysłowie.

${ }^{2}$ To prawdopodobieństwo 1 do $10^{40000}$, czyli w porównaniu Freda Hoyla, ,że tornado przechodzące nad złomowiskiem zbuduje ze znajdujących się tam odpadów Boeinga 747" (Caroll 2017, 342).
} 
od nieożywionych), autonomiczne przemiany termodynamicznych układów fizyczno-chemicznych i ich funkcjonowanie w organizmach (bakteriach, roślinach czy zwierzętach), w których zachodzą procesy życiowe. Dalej, trzeci wymiar, od drobnych powiązań, większych połączeń i zależności między grupami organizmów żywych do relacji między organizmami w skali całej biosfery, we wzajemnych masowych procesach życiowych organizmów i biocenoz (Weiner 2020, 24). Inny wymiar życia w „przyrodzie” życia pozaziemskiego, w naszej ziemskiej formule węgla i tlenu czy też na innej zasadzie ożywionej materii (wymiar jeszcze nieodkryty, ale możliwy). I wreszcie ostatni wymiar przyrodzony wyższych przejawów osobliwości życia - w człowieku świadomym istnienia życia na zewnątrz (w innych bytach ożywionych) i świadomym życia wewnątrz (w sobie) oraz - jak określa Eberhard Schockenhoff - ludzkie ,żywe ciało jako funkcjonalna całość”, „życie jako wyraz świata wewnętrznego", „życie jako manifestacja wolności”, ,życie jako spotkanie” i ,życie jako konieczność śmierci” (Schockenhoff 2014, 14-24).

Ten ostatni wymiar osobliwości (fenomenu) życia jest szczególnie ważny nie tylko dlatego, że jest ludzki, że dotyczy nas samych jako istot żywych, ale też dlatego, że wiąże się z życiem nadprzyrodzonym, o którym wiemy już więcej $\mathrm{z}$ innych źródeł poznania. Chociaż w wymiarze biologicznym nadal nie znamy odpowiedzi na pytanie, czym jest życie i skąd pochodzi, to teologia odkrywa w naszym życiu osobowym istotne znaczenie życia w innych bytach ożywionych (zwłaszcza innych ludzi) oraz świadomość wartości własnego życia, w nas samych.

Cytowany Autor Etyki życia w poszukiwaniu odpowiedzi na pytanie: czym jest życie?, słusznie zaznacza dwojaki sposób pojęcia, czym jest ta osobliwość w zależności od pola widzenia obserwatora lub uczestnika: „Czy odpowiada to specyfice i różnorodności życia, jeżeli wywodzi się je z tego, co nieożywione i opisuje się jedynie jako ogólne zjawisko, jako życie «W sobie», jako proces przejścia przez jego określone formy [...]?” (Schockenhoff 2014, 9). Zarówno samo pytanie, jak i odpowiedź na nie, są zależne od sposobu widzenia „oddolnie"; odpowiedź może być standardowa, biologiczna, ze zredukowanej perspektywy zewnętrznego obserwatora. W takim ujęciu „określenie naukowe cechy «życie» może wyrazić, czym różni się kwiat albo roślina, palma albo żaba od rzeczy nieożywionej, jak kamień albo kawałek drewna. Nie daje ona jeszcze żadnej informacji na temat każdorazowego nosiciela tak określonego życia, na temat podmiotu, któremu przysługuje życie [i] na każdym etapie, już na najniższym etapie jednokomórkowców, życie występuje jedynie w odrębności konkretnej formy i postaci, a nigdy jako nieuformowana moc albo bezkształtno-sferyczna energia ponad konkretną formą życia [...]" (Schockenhoff 2014, 9-10). To samo pytanie już nie z pozycji obserwatora, ale uczestnika, może pociągnąć za sobą odpowiedź „od wewnątrz”, z doświadczeniem uczestnika życia, jego 
wyższych poziomów, jako ,poszerzona perspektywa percepcji z punktu widzenia osiągniętej wysokości spogląda na wstępne etapy świadomości, ducha i wolności” (Schockenhoff 2014, 14), jako specyficznie ludzkie formy życia.

\section{Wyjątkowość i nieśmiertelność życia ludzkiego}

Życie ludzkie jest w swojej istocie bardziej złożone, na wyższym poziomie niż życie biologiczne, fizyczno-chemiczne, przyrodnicze, tak jak wyższa jest osobliwość określająca cechy materii ożywionej od materii nieożywionej. Jest to jednocześnie różnorodność życia z odrębnością poszczególnych jego form: życie roślin, zwierząt i człowieka. Ewolucjonistyczne argumenty wyprowadzające istnienie człowieka z innych istot żywych (jako „nagiej małpy”) wydają się niewystarczające wobec pełnej prawdy o człowieku i redukują byt ludzki do innych bytów ożywionych w bardziej podstawowych, niższych jednostkach ontologicznych (Morris 1974). Współczesna nauka już w sposób pewny wyróżnia istnienie: materii nieożywionej, życia (materii ożywionej) i świadomości (rozumności) życia ludzkiego, co nie oznacza jednak, że znane są przyczyny, sposoby powstania kolejnych etapów świata materialnego, ożywionego i ludzkiego. Tu jednocześnie kończy się poznanie racjonalno-empiryczne; biologia, fizyka i - jak wyjaśnia Papież Jan Paweł II - przejście życia ludzkiego na wyższy poziom otwiera jego poznanie metodami filozoficznymi i teologicznymi (Maziarka 2019, 89-90).

Dziś nie jest problemem rozumienie różnic między zwierzętami a człowiekiem w ujęciu z jednej strony ewolucyjnie (Kieroń 2015, 253-256), a z drugiej strony antropologicznie, biblijnie i filozoficznie. Jedna strona zgadza się już na istnienie różnic fizycznych (mózg, krtań), behawioralnych (specyficzne uczucia, działanie i relacje), rozwojowych (genetyka, charakterystyczna ontogeneza i długie życie) czy swoistych cech społecznych człowieka; druga strona podkreśla różnice jakościowe człowieka w postaci rozumności, wolnej woli, języka słownego, kultury, a przede wszystkim duchowości (Pismo Święte doda jeszcze wyjątkowość osoby ludzkiej w centrum stworzenia, rozróżnienie dobra i zła, wezwanie do „panowania” nad innymi istotami żywymi) (Góźdź 2011, 487-488).

Egzystencjalny opis człowieka podkreśla wytwory kultury w życiu ludzkim: od materialnego przetwarzania środowiska, techniki i dzieł umysłowych (gromadzenia wiedzy, twórczość pisana, rozwijanie różnych nauk), przez kulturę estetyczną, sztukę i wyrażanie piękna, kulturę społeczną, politykę i ekonomię, dalej - przez refleksję nad samym sobą, z badaniem własnej natury, sensu i celu istnienia, do tworzenia kultury moralnej, jako wyraz wolności wyboru z dążeniami ku wartości prawdy, sprawiedliwości i miłości. W końcu egzystencjalny opis człowieka dochodzi do kultury religijnej, filozofii i teolo- 
gii, które wyrażają najwyższy pułap duchowego rozwoju człowieka, przy jednoczesnej niemożności przezwyciężenia jego niedoskonałości, słabości „,bytowej i moralnej, udręk i śmierci" (Granat 2013, 69-80).

Do tego obrazu życia ludzkiego, jego cech i znaczeń, dochodzi wielowiekowa refleksja filozoficzna na temat natury człowieka jako osoby (od definicji Boecjusza: persona est naturae rationabilis individua substantia, do Spaemanna „różnicy między czymś a kimś”), jego intencjonalności, transcendencji, podmiotowości, duszy, sumienia i wolności (Spaemann 2001) oraz opisując już tylko hasłowo - refleksji teologicznej o życiu w ogóle (Kiernikowski 2009, 7-17), o życiu ludzkim w kontekście stworzenia (Kijas 2004, 68-97), o człowieku w Jezusie Chrystusie (Scola 2005, 145-210) i o człowieku przebóstwionym (Gryz 2009, 8-20, 419-424).

Pytania o życie ludzkie zdają się szukać właściwej odpowiedzi przede wszystkim w perspektywie teologicznej, chociaż sam ,człowiek jest tajemnicą (mysterion) pierwszą po misterium Boga, a właściwie Bóg i człowiek stanowią wspólną tajemnicę. Nie wiemy bez reszty, «czym» jest człowiek, «kim» jest człowiek, jakie są jego fundamentalne struktury i jaka jest jego właściwa historia - od zaistnienia po trwanie po śmierci" (Bartnik 2012, 375). Nie jest to jednak empiryczna bezradność nauki w poszukiwaniu początku człowieka z materii i ewolucji, ale duchowe poznanie tajemnicy człowieka poprzez Objawienie i ponadprzedmiotowe odniesienie człowieka do Stwórcy. Początkiem życia ludzkiego i początkiem człowieka jest stworzenie przez Boga, czyli „wyłączna i w pełni transcendentna relacja do Boga, jako jego początku i celu". Pozwala to - niezależnie od trudności ze zrozumieniem, czym jest życie człowieka - określić osobę ludzką przede wszystkim w odniesieniu do Boga (,teocentryzm człowieka”), w Jezusie Chrystusie („Bóg i człowiek są nieskończenie blisko siebie”), w drodze do celu - szczęścia, pełni życia (,historyczno-eschatologiczne dopełnienie") (Müller 2015, 143-144).

Z trzech postawionych we wstępie pytań o życie, pytanie o znaczenie życia (przede wszystkim ludzkiego) znajduje w antropologii teologicznej swoje urzeczywistnienie w jego wyjątkowości, ważności, godności i wieczności. Z kolei właśnie kontynuacja ziemskiego życia ludzkiego w wieczności stanowi eschatologiczny i soteriologiczny punkt wyjścia do przebóstwienia człowieka, czyli jego udziału w życiu samego Boga, Stwórcy wszelkiego życia. Od poziomu ludzkich pragnień, „w najskrytszej głębi osobowej natury człowieka tkwi potrzeba wzrastania, wychodzenia «ponad siebie», osiągania wyżyn przekraczających stan obecny” (Zabielski 2011, 173) przez „duchowe wzrastanie i upodobnienie się do Boga” w Jezusie Chrystusie, do „partycypowania w trynitarnym poznaniu Boga i w dzieleniu miłości osób Bożych: Ojca, Syna i Ducha [...] «twarzą w twarz» $(1$ Kor 13,12), «takiego jakim jest» (1 J 3,2)" (Müller 2015, 186) przez całą wieczność (por. J 17,3). 


\section{Kwestia życia ludzkiego u Karola Wojtyły - Jana Pawła II}

Poza teologiczno-antropologicznym uzasadnieniem znaczenia życia ludzkiego skierowanego ku wiecznemu przebóstwieniu, ze względu na osobowy, wyższy stan życia ludzkiego, w doświadczeniu istnienia rozumnego i wolnego, życie człowieka ma znaczenie moralne, wartość moralną. Najpełniej, najlepiej oddaje tę wartość sformułowana przez Jana Pawła II „Ewangelia życia” w encyklice Evangelium vitae na temat wartości i nienaruszalności życia ludzkiego: „Człowiek jest powołany do pełni życia, która przekracza znacznie wymiary jego ziemskiego bytowania, ponieważ polega na uczestnictwie w życiu samego Boga. Wzniosłość tego nadprzyrodzonego powołania ukazuje wielkość i ogromną wartość ludzkiego życia także w jego fazie doczesnej [...] dzisiaj, gdy lęk budzą coraz liczniejsze i poważniejsze zagrożenia życia ludzi i narodów, zwłaszcza życia słabego i bezbronnego" (Jan Paweł II 1995a, 2, 3).

Pokazana w encyklice antropologia i teologia moralna o życiu ludzkim stała się jednym $z$ centralnych tematów papieskiego pontyfikatu, a wcześniej - jeszcze w czasie studiów Wojtyły w Rzymie oraz w okresie pracy naukowej na KUL $\mathrm{w}$ Lublinie - była jednym z głównych przedmiotów Jego zainteresowania. Kwestia człowieka i jego życia przebija się w Jego dwóch podstawowych dziełach antropologicznych (Wojtyła 1986; Wojtyła 1994), które analizują fenomen człowieka zarówno w kontekście ludzkiej miłości, jak również w kontekście ludzkiego czynu. Opis człowieka w ujęciu fenomenologicznym Karola Wojtyły nie tylko przedstawia istotę osoby ludzkiej, ale ukazuje ją w praktyce codziennego życia zarówno w relacjach międzyludzkich, jak i w odniesieniu do Boga.

Praktyczna troska o ludzkie życie towarzyszyła księdzu profesorowi i biskupowi Wojtyle od samego początku jego kapłańskiej i naukowej drogi. Uprawiana przez niego filozofia życia nabierała cech swoistego dwutaktu teorii i praktyki (Brzózy 2002). Z jego antropologicznych analiz fenomenu życia ujawniała się nadprzyrodzona godność ludzkiego istnienia, która stoi ponad jakimkolwiek interesem politycznym, społecznym, naukowym czy ekonomicznym, a z poważnego namysłu nad Objawieniem wypływa postawa szacunku dla każdej osoby ludzkiej, od poczęcia aż do naturalnej śmierci. Już w czasie posługiwania Kościołowi krakowskiemu przyszły Papież patronował różnym inicjatywom obrony życia, pisząc np. do uczestników sesji naukowej na temat problemu przerywania ciąży: „Oby Bóg pozwolił nam wspólnie służyć życiu” (Wojtyła 1977, 1). Powstają zręby Ewangelii życia, szerokiej formuły nauczania o życiu ludzkim, jego sensie i znaczeniu, która później zasilona „Ewangelią życia" z encykliki pod tym samym tytułem, stanie się kluczem do lepszego zrozumienia życia człowieka, ukazania jego godności i potrzeby jego ochrony.

Zanim w 1995 r. Jan Paweł II przedstawi w „Ewangelii życia” swoje orędzie o zagrożonym życiu ludzkim, sprzeciwi się zamachom na jego świętość 
i nienaruszalność oraz przedstawi założenia nowej kultury życia ludzkiego; będzie mówił w swojej pierwszej encyklice Redemptor hominis o prawach człowieka (Jan Paweł II 1979a, 17), a w encyklice Veritatis splendor powie o prawach osoby ludzkiej i wymaganiach moralnych życia ludzkiego w wymiarze indywidualnym, rodzinnym, społecznym i politycznym (Jan Paweł II 1993, 101). Później w encyklice Fides et ratio, o relacjach między wiarą i rozumem, Papież będzie pytał w ogóle o życie człowieka: „kim jestem, skąd przychodzę i dokąd zmierzam, co czeka mnie po tym życiu" (Jan Paweł II 1998a, 1) i wielokrotnie będzie wypowiadał się o życiu ludzkim w szeregu dokumentach i przemówieniach, zwłaszcza w słowach skierowanych do lekarzy, naukowców, prawników i ludzi zajmujących się problemami związanymi z życiem ludzkim.

Wrażliwość etyczna profesora i biskupa krakowskiego przenosi się na cały pontyfikat Papieża Jana Pawła II, który - jak chyba żaden inny Jego poprzednik - bardzo często podejmuje problem życia ludzkiego w kontekście jego godności, jego nadprzyrodzonych celów, demaskując równocześnie realne współczesne jego zagrożenia. Świadczą o tym liczne teksty papieskiego nauczania, które można wykorzystać w filozofii, medycynie, biologii i innych naukach o człowieku (W trosce o życie 1998; W trosce o życie 2012). Nie bez znaczenia jest również fakt, że Papież Polak powołał szereg komisji i komitetów watykańskich (np. Papieską Komisję ds. Duszpasterstwa Służby Zdrowia w 1985 r., Papieską Akademię Pro Vita w 1994 r. czy Papieską Radę ds. Rodziny w 1981 r.), zajmujących się różnymi aspektami życia ludzkiego, które uzupełniają papieskie wypowiedzi o człowieku szeregiem instrukcji, deklaracji, komunikatów bioetycznych wygłoszonych na licznych konferencjach (The nature and dignity 2003).

\section{Evangelium vitae Jana Pawła II w centrum jego Ewangelii życia}

Zarówno w nauczaniu Jana Pawła II o życiu ludzkim, jak i w nauczaniu Magisterium Kościoła katolickiego na ten temat, największy autorytet ma wspomniana wyżej encyklika Evangelium vitae (wydana 25 marca 1995 r.) z podtytułem: „O wartości i nienaruszalności życia ludzkiego”, co wskazuje na to, jakie będzie całe przepowiadanie o życiu ludzkim w tym dokumencie. W centrum „Ewangelii życia”, czyli „Dobrej nowiny o życiu”, znajduje się

\footnotetext{
${ }^{3}$ W Międzywydziałowym Instytucie Bioetyki Uniwersytetu Papieskiego Jana Pawła II pod kierunkiem dyrektora Instytutu ks. prof. dr hab. Krzysztofa Szczygła podjęto w 1997 r. inicjatywę zebrania wybranych dokumentów Magisterium Kościoła katolickiego na tematy związane z szeroko pojętym życiem (bioetyki, medycyny, biologii i ekologii). Przeważającą część tego nauczania, dotychczas w dwóch tomach, stanowią teksty Jana Pawła II.
} 
teza: „tylko zgodna współpraca wszystkich, którzy wierzą w wartość życia, pozwoli uniknąć klęski cywilizacji i jej nieobliczalnych konsekwencji” (Jan Paweł II 1995a, 91). „Ewangelii życia” Papież przeciwstawia wszystkie przejawy cywilizacji śmierci: niszczenie poczętego życia, śmiercionośne eksperymentowanie na embrionach, wykorzystywanie nienarodzonych jako źródło narządów do przeszczepów, zabójstwo, samobójstwo, eutanazja i inne przejawy braku szacunku dla życia (Jan Paweł II 1995a, 58-67; Sala 1997, 295-302).

Jan Paweł II nie zatrzymuje się jednak na wyliczeniu przejawów zagrożeń dla życia ludzkiego we współczesnej cywilizacji, ale przede wszystkim podaje pozytywny wykład o życiu pochodzącym od Boga i należącym do Boga. Fundamentem, na którym buduje „Ewangelię życia”, jest biblijne Objawienie (jest to chyba najbardziej „ubiblijniona” encyklika) (Chmiel 1995, 13), z którego Papież wyprowadza zasadę moralną: „Życie pochodzi od Boga, jest Jego darem, Jego obrazem i odbiciem, udziałem w Jego ożywczym tchnieniu. Dlatego Bóg jest jedynym Panem tego życia: człowiek nie może nim rozporządzać” (Jan Paweł II 1995a, 39). „Ponieważ życie ludzkie jest święte i nienaruszalne w każdej swej fazie i kondycji; jest ono dobrem niepodzielnym”; „trzeba «zatroszczyć się» o całe życie i o życie wszystkich. Więcej - trzeba dotrzeć jeszcze głębiej, do samych korzeni życia i miłości” (Jan Paweł II 1995a, 87).

W papieskiej Ewangelii życia znaczące miejsce zajmuje również nauczanie o małżeństwie i rodzinie (Jan Paweł II 1995a, 11, 26), z niezwykłą wizją życia ciała ludzkiego oblubieńczego, odkupionego i zmartwychwstałego. W latach 1979-1984 w nauczaniu katechetycznym podczas audiencji generalnych Jan Paweł II zbudował nie tylko nowoczesną teologię ciała (małżeństwa i rodziny), ale na bazie swych przedpapieskich studiów etycznych i tez encykliki Pawła VI Humanae vitae (Tettamanzi 1993, 136-148) omówił również „uzgadnianie miłości małżeńskiej z poszanowaniem życia ludzkiego” (Jan Paweł II 1998b, 114).

Jan Paweł II powiedział zresztą o swojej Ewangelii życia i „Ewangelii życia”, m.in. do świeckich członków ruchów Pro Vita, także małżonków i rodziców, kilka miesięcy po wydaniu Evangelium vitae: „Publikacja encykliki była z pewnością przełomem w dziejach ruchu na rzecz życia” - i dalej: „doprawdy szeroki jest horyzont, jaki otwiera się przed waszą misją, obejmuje on również tak niezastąpioną wartość jak wychowanie młodzieży i rodzin do miłości prawdziwej, wiernej i czystej. Nierealistyczny jest pogląd, że można zbudować trwałą kulturę życia bez poważnego wychowywania sumień, a zwłaszcza bez autentycznego przywiązania uczuciowego do wartości rodzinnych. Są to wstępne przesłanki prawdziwej strategii obrony życia, których znaczenie okazuje się coraz większe" (Jan Paweł II 1995c, 2-5).

To w obszarze relacji rodzinnych i małżeńskich, w prokreacji mężczyzny i kobiety ujawnia się chyba najgłębszy sens Ewangelii życia. Jeśli płodny akt 
małżeński pozbawi się perspektywy niepowtarzalności, wyjątkowości, miłości i duchowości, to poczęte życie ludzkie stanie się tylko biologiczną reprodukcją, z parametrami skuteczności i wydajności. Natomiast jeśli początek życia ludzkiego w kontekście antropologicznej przesłanki o wyjątkowości człowieka nie zostanie pozbawiony tej perspektywy, to ujawni się wartość życia ludzkiego nieredukowalna do świata rzeczy, świata biologii, materii czy nawet życia innych istot pozaludzkich, określana jako godność człowieka (Bortkiewicz 2004, 68). „Perspektywa teologiczna poszerza, czy też pogłębia ten kontekst. Najdobitniej i zarazem najbardziej zwięźle wyraził to Jan Paweł II w Liście do Rodzin: «Gdy z małżeńskiej jedności dwojga rodzi się nowy człowiek, to przynosi on ze sobą na świat szczególny obraz i podobieństwo Boga samego: w biologię rodzenia wpisana jest genealogia osoby»" (Bortkiewicz 2004, 68).

\section{Ewangelia życia według Jana Pawła II nie tylko w encyklice Evange- lium vitae}

Dobra nowina o życiu znajduje swój wyraz w licznych wypowiedziach papieskich także $w$ trosce o osoby starsze, o chorych i niepełnosprawnych. Podobnie w sytuacji wojny, zbrojeń i przemocy, gdy również życie traci wartość i sens, warunkiem pokoju jest „refleksja nad świętością życia ludzkiego, nad wymogami sprawiedliwości i nad odrzuceniem gwałtu w jego licznych formach" (Jan Paweł II 1979b). To właśnie świadomość nienaruszalnej wartości życia stanowi zasadniczy fundament papieskiego sprzeciwu wobec wojny i wszelkich form przemocy.

Poza encykliką Evangelium vitae, w pierwszym rzędzie uwaga Świętego Papieża o życie ludzkie skupia się na życiu dzieci. Zarówno List do dzieci Tra pochi giorno (Jan Paweł II 1994b), nazwanym papieską „Ewangelią dziecka”, jak i inne wypowiedzi na temat zagrożeń życia dzieci, zwłaszcza nienarodzonych, świadczą o znaczeniu życia tych, którzy sami nie mogą się bronić. W tej postawie wyraźnie ujawnia się prawda o nienaruszalności życia, ponieważ właśnie w okresie prenatalnym i neonatalnym życie wymaga szczególnej opieki i szacunku (Jan Paweł II 1988, 1).

W tym kontekście zmaganie o respektowanie prawa do życia należy uznać za jedno z najpilniejszych zadań ludzkości na każdym etapie dziejów. Szczególne znaczenie należy przyznać papieskiemu głosowi sprzeciwu wobec prób ograniczenia prawa do życia jako działania moralnie niegodziwego, de facto niszczącego ludzkie życie. To nie tylko przypadki prawnie usankcjonowanej aborcji (np. dzieci niepełnosprawnych), ale również wykorzystania embrionów i płodów ludzkich w poszukiwaniach nowych terapii, najczęściej dla osób dorosłych, i w ogóle w badaniach eksperymentalnych. Jan Paweł II wielokrot- 
nie i bardzo zdecydowanie przypominał prymat życia ludzkiego w stosunku do najbardziej nawet szlachetnych intencji towarzyszących eksperymentom medycznym. Mówił m.in.: „Warto pomyśleć - aby pozostać w zakresie biologii i medycyny - o ukrytym niebezpieczeństwie, jakie dla prawa człowieka do życia wypływa z samych odkryć na polu sztucznego zapłodnienia, kontroli urodzin i płodności, hibernacji i «śmierci opóźnionej», inżynierii genetycznej, lekarstw w zakresie psyche, przeszczepów organu itp. Pewnie poznanie naukowe ma swoje prawa, do których się stosuje. Ono jednakże musi uznawać, nade wszystko w medycynie, nieprzekraczalną granicę w odniesieniu do osoby i ochrony jej prawa do życia w sposób godny istoty ludzkiej” (Jan Paweł II 1980, 3).

W badaniach naukowych, zwłaszcza na ludzkich zarodkach, Autor Evangelium vitae podkreślał, że „nie wolno zapominać, iż nauka sama nie może uzurpować sobie prawa do orzekania o transcendentnym pochodzeniu i ostatecznym przeznaczeniu ludzkiego życia" (Jan Paweł II 1994a, 2). Zwracając się do badaczy, lekarzy i całego systemu służby zdrowia, Papież często przypominał fundamenty ochrony życia w tradycji Hipokratesa i bronił takiej koncepcji medycyny, która przede wszystkim ratuje życie i leczy chorobę, uznając, że tylko Bóg jest Panem ludzkiego życia (Jan Paweł II 1983, 3).

Za papieską Ewangelią życia, kwestie związane z problemami ludzkiego życia są widoczne również w szeregu innych dokumentów Magisterium Kościoła katolickiego, które chociaż nie były w czasie długiego pontyfikatu napisane przez Jana Pawła II, to były mu znane i akceptowane. Z ważniejszych można wyliczyć Instrukcję Donum vitae (Kongregacja Nauki Wiary 1987), Kartę Pracowników Stużby Zdrowia (Papieska Rada ds. Duszpasterstwa Służby Zdrowia 1995) czy Deklarację o sztucznym przedłużaniu życia i dokładnym ustaleniu momentu śmierci (Papieska Akademia Nauk 1985). Tematy tych analiz o życiu ludzkim, wykraczające poza obszar teologiczny, wyraźnie wskazują, jak Ewangelia życia odpowiada na pytania życia ludzkiego (dylematy początku życia czy problemy kresu życia).

\section{Znaczenie Ewangelii życia według Jana Pawła II}

W jeszcze szerszej perspektywie Jan Paweł II widział życie w postaci przyrody ożywionej, która też ma wpływ na życie ludzkie, a także jak człowiek - w swoim życiu biologicznym związany z życiem innych istot żywych - oddziałuje na swoje środowisko życia, często je niszcząc, zatruwając i zanieczyszczając. Wspomniał o tym m.in. w przemówieniu do członków Papieskiej Akademii Nauk: „Rezultatem ludzkich błędów są często szkody wyrządzone środowisku i coraz większy niedobór zasobów naturalnych. Chociaż świat 
wytwarza dość żywności, by starczyło jej dla każdego, setki milionów ludzi cierpią głód, podczas gdy gdzie indziej ogromne masy żywności są marnotrawione [...] Ludzie muszą na nowo odkryć moralne znaczenie przestrzegania pewnych granic; powinni wzrastać i dojrzewać w poczuciu odpowiedzialności za każdy aspekt życia" (Jan Paweł II 1991, 5-6). Troskę o życie w przyrodzie, ochronę tego życia w środowisku człowieka określają trzy warunki moralne, które mają określać rozwój życia ludzkiego w środowisku przyrodniczym: „Pierwszy [...] polega na konieczności lepszego uświadomienia sobie, że nie można bezkarnie używać różnego rodzaju bytów, żyjących czy nieożywionych - składników naturalnych, roślin, zwierząt - w sposób dowolny, jedynie według własnych potrzeb gospodarczych. Przeciwnie, należy brać pod uwagę naturę każdego bytu oraz ich wzajemne powiązanie w uporządkowany system, którym właśnie jest kosmos. Drugi [...] opiera się na fakcie, poniekąd bardziej jeszcze niepokojącym, ograniczenia zasobów naturalnych, z których część jak się zwykło mówić - nie odnawia się. Używanie ich tak, jakby były niewyczerpalne, z nieograniczoną władzą, naraża na poważne niebezpieczeństwo możliwość korzystania z nich nie tylko przez obecne pokolenie, ale przede wszystkim przez przyszłe generacje. Trzeci [...] odnosi się bezpośrednio do skutków pewnego typu rozwoju dla jakości życia w strefach uprzemysłowionych. Wiemy, że skutkiem bezpośrednim czy pośrednim uprzemysłowienia jest coraz częściej zatrucie środowiska, niosące poważne konsekwencje dla zdrowia ludności" (Jan Paweł II 1987, 34). Nauczanie o znaczeniu życia ludzkiego w aspekcie ekologii (Jan Paweł II 1995, 99) kontynuuje papież Franciszek w encyklice ekologicznej Laudato si z 2015 r. (Franciszek 2015).

Chyba po raz pierwszy w historii cywilizacji to Karol Wojtyła - Jan Paweł II daje integralną, antropologiczną i etyczną odpowiedź na pytania o tajemnicę życia ludzkiego, o jego sens i znaczenie. Przede wszystkim jest to Ewangelia (Dobra nowina) niezwykłości i nienaruszalności życia, którego wartości nie można odnajdywać w świecie fizycznym, w świecie przyrody, w innych poza człowiekiem istotach żywych, czy - jak czytamy w encyklice Evangelium vitae - „wyłącznie w kategoriach wydajności ekonomicznej, nieuporządkowanego konsumpcjonizmu, atrakcji i przyjemności czerpanych z życia fizycznego zapominając o głębszych - relacyjnych, duchowych i religijnych - wymiarach egzystencji" (Jan Paweł II 1995, 23). Dobrze znaczenie tej encykliki oddaje Wanda Półtawska w lubelskim komentarzu: ,Jan Paweł wydaje dokument ostatni, który jest jakby syntezą wszystkich poprzednich i który bogatą treścią ogarnia całą rzeczywistość życia ludzkiego [...] Ten dokument wydaje mi się takim spojrzeniem ze szczytu, jakby z Orlej Perci ludzkiego żywota" (Półtawska 1997, 423).

Ewangelia życia, także z encykliki Evangelium vitae, ogarnia całą rzeczywistość życia biologicznego, przyrodniczego i ludzkiego, nadając przyrodzone i nadprzyrodzone znaczenie każdemu życiu, a wobec człowieka świadczy 
o niepowtarzalności, wyjątkowości, ważności i godności ludzkiego życia. Najmocniej jednak ukazuje wartość życia ludzkiego w perspektywie nadprzyrodzonej, przenosząc je w wieczność, łącząc życie ludzkie z życiem Boga, kierując je ku nieśmiertelności. Czy to będzie osobliwość życia w ogóle, życie biosfery, czy życie każdej rośliny, zwierzęcia czy wreszcie życie człowieka, od poczęcia do naturalnej śmierci, to właściwości duchowe Ewangelii życia najbardziej nadają sens istnienia wszelkiego życia. „Człowiek, [a przez niego wszystkie żywe stworzenia - J.B.] jest powołany do pełni życia, która przekracza znacznie wymiary jego ziemskiego bytowania [i] polega na uczestnictwie w życiu samego Boga" (Jan Paweł II 1995, 2).

\title{
Zakończenie
}

Nie tylko encyklika „o wartości i nienaruszalności życia ludzkiego” mówi o „Ewangelii życia”; papieska Ewangelia życia ludzkiego jest bardziej całościowa (w odniesieniu także do form życia pozaludzkiego) i bardziej adekwatna do poszukiwań odpowiedzi na pytanie o istotę osobliwości życia czy znaczenie, sens życia w przyrodzie. Z biologii i metafizyki życia trzeba przejść do teologii życia, czyli odnalezienia uzasadnienia dla godności życia ludzkiego w Bogu i w wieczności. Za życiem ludzkim opisanym jako osobliwość biologiczna, za życiem jako fenomenem osobowym warto dokonać wyboru Ewangelii życia Jana Pawła II: „budować, w duchu wolności i pełnego szacunku dla człowieka - cywilizację życia, która, aby zasłużyć na to miano, musi być także cywilizacją miłości” (Jan Paweł II 1995b, 4).

\section{QUESTIONS ABOUT HUMAN LIFE AND THE MEANING \\ OF THE GOSPEL OF LIFE OF JOHN PAUL II}

\begin{abstract}
SUMMARY
Natural sciences do not find a sufficient answer to questions about the phenomenon (singularity) of life in general and its meaning, the meaning of human life. Can these questions be answered from the point of view of a human being, who is either an observer of life from the outside or a conscious participant in life? What do theology and theological anthropology have to say in these matters, especially in the context of the creation and redemption of the human person?

In search of the meaning of human life and in response to questions about life in general, an important, adequate and universal answer is formulated by the concept
\end{abstract}


of the Gospel of life by Karol Wojtyła - John Paul II. The essence of this concept is contained in the encyclical of Pope John Paul II "Evangelium vitae" ("The Gospel of life") under the same title. In the lecture of the encyclical on life that comes from God, is given to man from God and directs man to live in God, we find, above all, the meaning of human life.

In the transition from the biology and metaphysics of life to the spiritual features of the Gospel ("Good News") of human life, which is unique, inviolable and extraordinary, John Paul II allows us to discover the meaning of life of every being, species and form of life on Earth.

Keywords: life, human life, encyclical, anthropology, "The Gospel of life", "Evangelium vitae", The Gospel of life, John Paul II

Słowa kluczowe: życie, życie ludzkie, encyklika, antropologia, „Ewangelia życia”, Evangelium vitae, Ewangelia życia, Jan Paweł II

\section{BIBLIOGRAFIA}

\section{Magisterium Kościoła katolickiego}

Jan Paweł II. 1979a. Encyklika „Redemptor hominis".

Jan Paweł II. 1979b. Godność osoby fundamentem pokoju.

Jan Paweł II. 1980. Osoba, nie wiedza jest miara i kryterium wszelkiego działania ludzkiego.

Jan Paweł II. 1983. Podstawy deontologii lekarskiej.

Jan Paweł II. 1987. Encyklika ,Sollicitudo rei socialis”.

Jan Paweł II. 1988. Trzeba raz jeszcze stwierdzić: każde życie jest święte.

Jan Paweł II. 1991. Przyrost ludności i bogactwa naturalne ziemi.

Jan Paweł II. 1993. Encyklika ,, Veritatis splendor".

Jan Paweł II. 1994a. Badania naukowe a etyka.

Jan Paweł II. 1994b. List do dzieci „Tra pochi giorno”.

Jan Paweł II. 1995a. Encyklika „Evangelium vitae”.

Jan Paweł II. 1995b. Powołani do budowania cywilizacji mitości.

Jan Paweł II. 1995c. W stużbie życiu ludzkiemu.

Jan Paweł II. 1998a. Encyklika ,Fides et ratio”.

Jan Paweł II. 1998b. Mężczyzna i niewiasta stworzyt ich, red. Tadeusz Styczeń, Lublin: RW KUL.

Kongregacja Nauki Wiary. 1987. Instrukcja o szacunku dla rodzacego się życia ludzkiego i o godności jego przekazywania „Donum vitae”.

Papieska Akademia Nauk. 1985. Deklaracja o sztucznym przedlużaniu życia i doktadnym ustaleniu momentu śmierci.

Papieska Rada ds. Duszpasterstwa Służby Zdrowia. 1995. Karta Pracowników Stużby Zdrowia.

\section{Literatura przedmiotu}

Bartnik, Czesław S. 2012³. Dogmatyka katolicka. Lublin: KUL.

Baturo, Wojciech. 2011. Najważiejsze teorie biologii. Warszawa: PWN.

Bortkiewicz, Paweł. 2004. Granice współczesnych interwencji w ludzkie życie. W: Fenomen życia w ujęciu interdyscyplinarnym, red. Andrzej Wójtowicz, 59-72. Poznań: Ośrodek Wydawnictw Naukowych. 
Brzózy, Zbigniew N. 2002. Od natury do etyki i religii. Karola Wojtyty filozofia człowieka. Poznań: Uniwersytet im. Adama Mickiewicza.

Caroll, Sean. 2017. Nowa perspektywa. Pochodzenie życia, świadomości i wszechświata, tłum. Urszula i Mariusz Seweryńscy. Warszawa: Prószyński i S-ka.

Chmiel, Jerzy. 1995. Biblijna struktura encykliki Evangelium vitae. W: Evangelium vitae. Dobra nowina o życiu ludzkim. Materiaty na temat encykliki „Evangelium vitae” oraz dyskusja o karze śmierci, red. Jerzy Brusiło, 13-17. Kraków: Wydawnictwo Naukowe Papieskiej Akademii Teologicznej.

Encyklopedia katolicka, red. Edward Gigilewicz. 2014. Lublin: Towarzystwo Naukowe Katolickiego Uniwersytetu Lubelskiego Jana Pawła II.

Góźdź, Krzysztof. 2011. Droga ku czlowiekowi. Lublin: KUL.

Granat, Wincenty. 2013. Ku czlowiekowi i Bogu w Chrystusie. Zarys dogmatyki katolickiej. Lublin: KUL.

Gryz, Krzysztof. 2009. Antropologia przebóstwienia. Obraz czlowieka w teologii prawostawnej. Kraków: UNUM.

Kiernikowski, Zbigniew. 2009. Drzewo życia w „środku” ogrodu. Pastores, 45 (4), 7-17.

Kieroń, Zuzanna. 2015. Swoistość człowieka współczesnego w oparciu o dane anatomiczne i morfologiczne. Perspektywa wertykalna. W: W poszukiwaniu osobliwości natury ludzkiej, red. Arkadiusz Gut, Zbigniew Wróblewski, 253-279. Lublin: KUL.

Kijas, Zdzisław J. 2004. Poczatki świata i człowieka. Kraków: WAM.

Lane, Nick. 2016. Pytanie o życie. Energia, ewolucja i pochodzenie życia, thum. Adam Tuz. Warszawa: Prószyński i S-ka.

Maziarka, Tomasz. 2019. Powstanie człowieka w ujęciu emergentyzmu. W: Powstanie człowieka w ujęciu interdyscyplinarnym, red. Tomasz Maziarka, 87-110. Kraków: Copernicus Center Press.

Morris, Desmond. 1974. Naga matpa, tłum. Tadeusz Bielicki, Jan Koniarek i Jerzy Prokopiuk. Warszawa: Wiedza Powszechna.

Müller, Gerhard L. 2015. Dogmatyka katolicka, thum. Wiesław Szymona. Kraków: WAM.

Półtawska, Wanda. 1997. Evangelium vitae świadectwem jednego życia. W: Jan Paweł II. Evangelium vitae. Tekst i komentarze, red. Tadeusz Styczeń, Janusz Nagórny, 417-425. Lublin: Redakcja Wydawnictw KUL.

Sala, Giovanni B. 1997. Ciągłość i nowość Evangelium vitae. W: Jan Pawet II. Evangelium vitae. Tekst $i$ komentarze, red. Tadeusz Styczeń, Janusz Nagórny, 287-306. Lublin: Redakcja Wydawnictw KUL.

Schockenhoff, Eberhard. 2014. Etyka życia. Podstawy i nowe wyzwania, thum. Konrad Glombik. Opole: Wydział Teologiczny Uniwersytetu Opolskiego.

Scola, Angelo. 2005. Osoba ludzka. Antropologia teologiczna, tłum. Lucjan Bartel. Poznań: Pallottinum.

Spaemann, Robert. 2001. Osoby. O różnicy między czymś a kimś, tłum. Jarosław Merecki. Warszawa: Oficyna Naukowa.

Tettamanzi, Dionigi. 1993. Encyklika Humanae vitae w nauczaniu Jana Pawła II, Communio. Międzynarodowy Przeglad Teologiczny, 75 (3), 136-148.

The nature and dignity of the human person as the foundation of the right to life. The challenges of the contemporary cultural context, ed. Juan de Dios Vial Correa i Elio Sgreccia. 2003. Vatican: Libreria Editrice Vaticana.

Weiner, January. 2020. Życie i ewolucja biosfery. Podręcznik ekologii ogólnej. Warszawa: PWN.

Wielka Encyklopedia Oxford, red. Hilary McGlynn. 2010. Warszawa: Oxford Educational E. M. Studio.

Wielka Encyklopedia PWN, red. Jan Wojnowski. 2005. Warszawa: PWN.

Wojtyła, Karol. 1977. Słowo wstępne. W: Specjalistyczne aspekty problemu przerywania ciąży. Kraków: Polskie Towarzystwo Teologiczne. 
Wojtyła, Karol. 19864. Miłość i odpowiedzialność. Lublin: TN KUL.

Wojtyła, Karol. 1994³. Osoba i czyn oraz inne studia antropologiczne. Lublin: TN KUL.

W trosce o życie. Wybrane dokumenty Stolicy Apostolskiej, red. Jerzy Brusiło. 2012. Tarnów: Biblos.

W trosce o życie. Wybrane dokumenty Stolicy Apostolskiej, red. Krzysztof Szczygieł. 1998. Tarnów: Biblos.

Zabielski, Józef. 2011. Teologiczno-antropologiczna zasadność przebóstwienia człowieka. W: Abyśmy się stali synami Bożymi, red. Ireneusz Mroczkowski, Jarosław A. Sobkowiak, 173-192. Warszawa: UKSW.

Zięba, Stanisław. 2020. Informacyjny wymiar wszechświata, życia i człowieka. Warszawa: PWN.

Jerzy Brusilo OFMConv - ur. 1961 r. w Wałbrzychu, prezbiter Prowincji św. Antoniego i bł. Jakuba Strzemię Zakonu Braci Mniejszych Konwentualnych (franciszkanów), dr hab. teologii, adiunkt w Instytucie Teologii Praktycznej i Instytucie Bioetyki UPJPII, wykładowca etyki na Uniwersytecie Rolniczym im. Hugona Kołłątaja w Krakowie, krajowy duszpasterz lekarzy weterynarii. 